\title{
roy
}

\section{An Outline of Studies Recommended to a Young Officer}

\section{Col. W. H. M. Dixon R.A.}

To cite this article: Col. W. H. M. Dixon R.A. (1862) An Outline of Studies Recommended to a Young Officer, Royal United Services Institution. Journal, 6:21, 84-99, DOI:

10.1080/03071846209415929

To link to this article: http://dx.doi.org/10.1080/03071846209415929

\section{曲 Published online: 11 Sep 2009.}

Submit your article to this journal

Џ Article views: 5

Q View related articles $\widetilde{2}$ 


\title{
LECTURE.
}

Friday, January 31st, 1862.

Major-Gesemal IV. WATKINS in the Chair.

\section{AN OUTLINE OF STUDIES RECOMMENDED TO $A$ YOUNG OFFICER.}

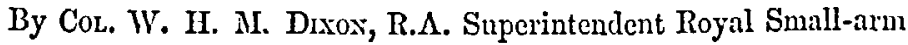 \\ Factories, Fnfield.
}

Ir has been said that "Military habits and organization are conducive to the best interests of society, even during a period of profoundest peace."

Accepting this statement in its evident meaning, viz. that perfection of cliscipline, training, and education in military men reflects not only honour and renown upon themselves, but is the true safeguard for the public weal, it will be my object to show to my younger brother officers how universally this truth is acknowledged, by what means its accomplishment is sought for in foreign armies, and how it can be obtained in our own.

Incidentally I must also touch upon the education, in some respects, of the soldier, as having a certain connection with that of the officer.

It is quite unnecessary for me to cite examples of the benefits conferred upon countries, and even the world at large, by accomplished and successful generals, or to point ont the opposite results entailed upon lingdoms and empires by the weakness and ignorance of those military leaders to whom great interests had been committed.

Warfare as conducted by civilized nations is more dependent upon the results of scientific arrangements and combinations than upon mere physical or brute strength.

The object of a war is undonbtedly to cripple or destroy the material forces and defences of the enemy; but the general who accomplishes this object with the least loss to his own army is acknowledged to be a master in the art of war.

We can easily see the force, and acknowledge the correctness, of the statement of a French writer, who says that battles are the mere accidents of modern civilized warfare. For instance, two armies entering the field 
in opposition to each other will eventually endeavour by a system of wellconsidered nancuvres to obtain possession of some point the occupation of which will exercise some very decided influence upon the results of the campaign.

On the supposition that both armies are equally well handled, and each has an equal start, if we may so call it, the probabilities will be that the operations of both armies will finally lend to a battle in order todecide upon the possession of this point.

On the other supposition-and the most natural because the most common one-of a difference in the quality of the generalship of the two armies, then it would most probably happen that the army best commanded would succeed in securing this objective point without the necessity of a battle, and, if so, would have sccured a double advantage.

Again, the nost skilful generalship is required at times to avoid the risk of being drawn into action upon unequal terms, or upon unfavourable ground.

On the other hand, to choose his own time, to manceurre skilfully and confidently in presence of an enemy, and finally to take advantage of a faulty disposition to strike his blow, is the mark of a consummate general and accomplished soldier. I could not cite a better example of this than the lengthened manceuvres which preceded the battle of Salamanea fought by the Duke of Wellington on the 22nd July, 1812.

'These illustrations will snfficiently explain the meaning of the statement that " those great military scenes - which we designate by the nane of battles are more the accidents of warfare than its principal or leading objects."

IInving thus thoroughly imbued ourselves with the feeling of the importance to be attached to true generalship, wc have only to agree to the proposition that there are no "heaven-born" generals in order to grapple fairly with the subject before us this aftermoon, and to consider the description of studies necessary for a young officer to pursue, in view of his advancement to and employment in the highest ranks of his profession.

By the term "education of a young officer," which of course is the result involved in the studies recommended to be pursued by him, I understand not only the professional training required to be gone through to fit him for the varied military duties he may have to perform as a matter of duty, but also the developement to the utmost extent of all his faculties and energies towards the attainment of honourable distinction in his career.

In setting out with a high standard I do no more than any member of the learned professions might be expected to do, and whose example should hardly require to be much insisted upon by me in laying down my argnment.

One supreme conviction ought to weigh with every officer who receives a commission, viz. that it is a trust committed to him by his country, a confidence reposed in hin, and for no selfish or individual ends.

From this conviction springs the sense of duty as an incentive to action, and this is emphatically the lever which I must employ, as others have before me, to stimulate my younger brethren to exertion.

Well, then, if we sturt with the conviction that some military stuly is 
necessary for every officer after he has entered the profession of arms, we may also lay down as a rule that successful study will be honourable to him.

It is worthy of remark that the periods at which scientific military education has most engrossed the attention of the great military monarchies of Europe are those in which great military operations have brought into strong relief the wants of the different armies engaged. During and after the Seren Ycars' War (a perind which saw much of the present military schools and colleges spring into existence), the French levolutionary war, and more recently the Russian war, the student of nilitary history will see how indefatigably endeavours have been made to inprove the education of the officers of the army.

Since the termination of the war with Russia, the whole public roice of England has called for a better education for our officers, and particularly for the staff of our army. The deep interest which the general public fecls in the result of any war in which our country may be engaged makes them feel all the importance of having the fortunes of the country committed to able and competent heads as well as strong arms. If we turn to the Memoirs of Frederick the Great, we see the same anxious solicitude for the proper training of his officers, and the same complaints upon the inefficiency of his staff.

$\Lambda$ the termination of the Seven Years' War he writes: "The position of the soldier may be left as it was before the war began; but the position of the officer is a point to which I am devoting my utmost care. In order in future to quicken their attention whilst in service, and to form their judgment, $I$ have ordered them to receive instruction in the art of war, and they will be obliged to give reasons for all they do. Such a plan will not answer with every one; still, out of the whole body, we shall certainly form some men and officers who will not merely have their patents as generals to show, but some capacity for the office as well." And, again, in describing the difficulties in the way of impressing upon the minds of his young nobility the necessity for military study and training, he says: "They shrink from the army because it is a real training for the character; nothing is passed over in a young officer-he is obliged to maintain a prudent, regular, and sensible conduct. This is precisely what they dislike, and one hears the nbsurd and insolent expression, 'If my boy will not work, he will do none the worse for a soldier.' Yes, he may do for a mere man-at-arms, but not for an officer fit to be advanced to the highest commands, the only end of a good soldier's life, and which requires really extensive knowledge."

What Frederick the Great was then anxious for-what France and the other great military monarchies of Europe have, by different plans and with varied success, been striving after-viz., the highest degrec of education capable of being imparted to an officer-presupposes, as a rule, a condition of obligatory work on the part of the officer. It is necessary for me to touch upon the objects sought to be attained by the obligatory system, and the results arrived at, as showing what is considered necessary for an officer to know, and how this knowledge is expected to prepare him for filling with credit the higher branches of his profession.

Jn the carly part of 1850 , a commission, composed of two officers and 
a civilian, was appointed by the Secretary of State for War, " to consider the best mode of re-organizing the system for training officers for the scientific corps."

The commission furnished a Report on the specific subject to which their attention was directed, and also added to it " $\Lambda \mathrm{n}$ Aecount of Foreign and other Military Education." This leport has been published in the form of a Blue Book, and contains the most interesting mass of information upon the subject of military education that has ever been collected together.

I intend to employ this Report as my text-book whenever I appeal to what is going on abroad or to the opinions of foreign military sarans.

Frasce.-In France there is a very broad distinction drawn between the requirements for an officer of the scientific corps and an officer of the line; for, while in the former case every endeavour is made to impart very high mathematical knowledge, in the latter a rery moderate amount is considered sufficient. Let us take, for example, the Mrilitary College of St. Cyr. $\Lambda$ fair, but by no means extensive, Jnowledge of mathematics is required for the entrance examinations only into this college. With the exception of some lectures on descriptive geometry and physical seience applied to military art, the main teaching consists of military art and literature, history, geography, military statistics, fortification, and modern. languages.

The whole system of instruction in this school is of a highly practical and useful nature. Young men intended for the cavalry are instructed in infantry and artillery movoments and drill; just as those intended for the infintry are taught riding, and receive instruction in cavalry, as well as artillery drill and movements. This is considered a most important part of their instruction. " $\mathrm{It}$ is this," said the Gencral Commandant, "that made it practicable, for example, in the Crimen to find among the old ćleves of St. Cyr officers fit for the artillery, the engineers, and the staff; and for gencral officers, of course, it is of the greatest advantage to have known, from actual study, something of every branch."

I think that the system at St. Cyr shows more truly the peculiar military genius of the French nation, and what is required for an officer's education, than that at the Polytechnic School. At this latter there is a mixture of the military and civil elements; the higher prizes are those for the civil departments of the Gorernment; and the traditions of the school, together with the high standing of its many distingnished scientific eleves, have all tended to keep up a very high mathematical standard, to the exclusion of literary and classical studies.

Agreeing that mathematical knowledge is necessary for the scientific corps of the army, and that it is a good educating agent for the mind and judgment, I am not at all convinced that the process of intense and almost exclusive application to such a study is one either called for by any branch of the army or calculated to make what is required-viz., a practical, as well as a theoretical, soldier.

It is eren a question among distinguished French officers whether this process, as pursued at the Polytechnic, is not an cxhaustive one to the brain of many of these young men, and injurious to them eventually. Excessire mental, as well as physical, training produces similar results; 
and while in the Army we may for particular services require a better and more elaborate educational training than for others, yet in both the condition of a healthy, vigorous, active bodily frame is a sine quâ non.

The French may justly regard the Polytechnic as a great national institution-superior, very possibly, to anything of the sort in the world. But we must bear in mind that it is not purely a military school, and that very frequently those who get into the Artillery and Engineers are the lowest qualified of that school.

STAFF CORPS.-The entrance into the staff corps in France is through the school of application for the staffs, and the twenty-fire annual vacancics in this school are filled up by three pupils from the Polytechuic and by a competitive csamination between the pupils of St. Cyr and second lieutenants of the army. The vacancies mostly fall to the share of the pupils from St. Cyr. This at once opens out $a$ wide career for an intelligent and ambitious officer. Once he is attached to the staff, from the result of a tro-years' successful study at the staff school, he permanently belongs to it.

The course of study is worthy of remark, as combining in a high degree all the essential elements which constitute an efficient staff officer. They are: descriptive gcometery, astronomy, topography and geodesy, geography and statistics, artillery, fortification, military art, military administration, mancuves, German, drawing, kecping of menorandumbooks, conduct and discipline, riding and knowledge of the horse. The work is done to some extent out of doors-such as military sketching; making plans of country, with and without trigunometrical points and distances; and plans of fields of battle, with descriptive notes and remarks.

It is worthy of remark that in France not much value is attached to any but compulsory study or training.

In their military schools we find that the young men do not study much by themselves. Whaterer lectures they attend and take notes of are subsequently carefully and systematically gone over with them by a set of instructors, called, from their oflice, répétileur's. The great object is to give their officers, or that portion of them who do not rise from the ranks, a careful professional cducation.

In the Artillery and Engineers this is principally given at MLetz, and an extensive practical training is given to these officers after they enter the service, first by their remaining with the troops until they attain the rank of second captain, and subsequently being employed in the arsenals, workshops, and fortified places.

$\Lambda$ short account of the regimental schools for the artillery and engineers of the French scrvice will be very interesting, as bearing considerably upon the direct subject of my lecture.

These regimental sehools are intended for the instruction, both theoretical and practical, of officers, particularly those promoted fron the ranlss, non-commissioncd officers, and private soldiers.

It must be borne in mind that a considerable number of officers rise from the ranks in the French service, and consequently have much to learn theoretically after getting their commissions. These schools therefore have a particular significance, as - showing that the French soldier when 
raised to the dignity of an officer is not left without further means being provided him for obtaining a good education, and thus qualifying him for pushing his fortunes without any limit beyond that of his own intelligence and desire for advancement.

In Marshal Vaillant's report to the Emperor on the organisation of the Imperial School of $A$ pplication for the Artillery and Engineers at Metz there occurs the following passage:-

"I beg to call your Mlajesty's attention to the dispositions of Article (55 of the Decree, by rirtue of which any officers of the artillery and engineers promoted from the rank of non-commissioned officers may be anthorised upon their own request to share in the instruction given at the School of $\Lambda$ pplication. It has scemed to me that the whole career of education ought to be opened to officers who, being less favoured by fortune than their companions, have not received the same advantages of instruction before entering the service."

The regimental schools may be thercfore considered as stepping-stones for this class, and also as furnishing the practical instruction in their profession to those officers who join their regiments from the School of Metz.

The instruction is broadly divided into tro distinct portions, viz., into summer and winter instructions, the former comprising the regimental instruction, or that which exists in the interior of the regiments, and which is directed by the chiefs of those corps who are responsible for it, with the means placed at their disposal, under the general surveillance of the commandant of the school; and the latter, or winter course, which requires the assistance of the special means of the schools, or the employment of its professors and matériel.

To a considernble extent the instruction is imparted by officers of the two corps, and particularly to the classes of non-commissioned officers and privates.

A professor of mathematics and fortification is attached to each school. At the end of each course general examinations are held, and lists made out in the order of merit, with noles of the capacity and aptitude of ench of the non-commissioned officers and men; and these lists are consulted in the formation of tables of promotion.

It is not to be supposed, however, that no professional teaching is given to officers of the line or caralry after joining their regiments. The following circumstance will partly show how this is attended to, and tend still further to exhibit the system of careful systematic instruction given to officers upon subjects which are peculiarly within their circle of duties.

I was travelling with several young officers on a professional tour on the Continent, including, besides; an inspection of fortified places and battle-fields and a visit to the French camps of instruction.

At one of the camps, I was inquiring about the instruction given to the regimental officers in the manouvre of a brigade and division, and how it was accomplished, I was told, that, previous to the brigade drill of the ensuing day, the regimental officers were informed of the nature of the movements it was proposed to execute, their object, and how they were to be carried out. $\Lambda$ sketch or plan of the movements was drawn up, and every young officer had the subject explainel to hin in a kind of 
regimental meeting presided orer by the commanding officer, the latter having had the information from the general of brigade. Instead, therefore, of any morements being executed i l'improviste, or without due consideration, the whole subject had been previously discussed, and each mancuvre shown to be $i k$ propos to some object, or subseriuent change of front or deployment. 'The camp was thus made one of positive instruction; and so systematic is the French military system on all subjects connected with the efficient drill, on intelligent and intelligible principles, of the offecer and soldier, that the drill of the brigade is completely mastered by all concerned before the divisional drill is allowed to be entered upon.

May we not be allowed to account for the acknowledged superior intclligence in all military matters of French soldiers, and their love for disctussing and criticising everything connected with professional subjects, by this system of giving rational explanations of the nature and object of military movements to all ranks, and thus enlisting on the side of wellconsidered and skilful combinations the intelligent apprecintion of the mass? Is there any good reason why such a system, carricd out even further, should not be introduced into our own service? I do not know that it would be advisable, on many grounds, to occupy a soldier's spare hours of an erening for such lectures or professional discussions, but an occensional alternation of a lecture instead of a drill would tend to vary the monotony of a camp life, by introducing a different subject to the notice of the soldier, and addressing his intelligence on points which arc to be made the matters of actual practice.

I have no wish to force attention too much to the condition of the army in a neighbouring country, but I cannot help alluding to the physical education which is going hand in hand with tha intellectual.

To an Englishman, who gcnerally dislikes anything systematic, and whose natural bias is shown by a studied independence and individuality of act and thought, it may seem a strange spectacle, the attempt to develope by a progressively systematic method the physical powers of a largc number of men, and for objects which are not immediately apparent.

And yet, according to recent accounts, most surprising results are being obtained by gymnastic drill or exercise on a very large scale, and its popularity is unquestioned.

Gronastics of the Frencil Ariry.-Mr. Steinmetz has given to the Institution a most valuable paper on this subject, and I cannot too strongly recommend every officer in the Army to procure a copy of the printed pamphlct. For both officer and soldier a physical training is pursued on a plan which must commend itself to every intelligent mind. These exercises to some extent take the part of drill; and, in fact, are preparatory to ordinary recruit drill.

The old Prussian system of setting up a recruit and teaching him to march, is superseded by one which is to teach him the full powers of his body, and so enable him to make use of his professional knowledge to the best advantage.

It would be of no advantage to a regiment composed of the most scientific men in the world to know that they unght to occupy a certain position, if, from defective training, a small amount of extra exertion had 
incapacitated them from the capability of making the effort necessary to reach that position.

This simple truth lies at the bottom of all the improrements which are taking place in the French Army, and which to some extent were strikingly exhibited in the late Italian enmpaign. I allude to the celerity of movement and rapidity with which the French soldiers closed with their enemy.

I should not have satisfactorily terminated my short account of French military education, had I omitted to notice the physical education as a portion of their system. Depend upon it, that no nation can afford to neglect this most essential point.

To officers of the English Army, who are as a race passionately fond of athletic sports, and pre-eminently distinguished in them beyond any other nation, this lesson must not be thrown away. You will as a rule have to depend in the field rnuch more on the physical powers of your men than on their intelligence. The latter it will be your province to gnide and instruct; the former must have been the result of careful training, and cannot be remedied at the decisive moment, if defective, by the best will on your parts.

I really do not see why proper instruction in some central gymnasium should not be afforded to a certain number of non-commissioned officers from the various services, on a principle similar to that adopted in the French Army; and this a good corps of Instructors raised for the $\Lambda$ rmy, who should be under the supervision of some central controi, similar to the Instructors of Musketry in their relation to the Commandant at Hythe.

I think cvery one will agree with me in the feasibility of the scheme, and, that it would become an exceedingly popular diversion, as well as. drill, amongst the soldiers of the army cannot be doubted by any onc. Yearly exhibitions might take placo in regiments or camps of the results of this training, and small prizes awarded to the most proficient. I think that this proposal would tend to improve the army physically, and morally also, as it would soon discover the drunkard, the dissatisfied, or the snlky man. Such games, as the results of careful early training, were very successfully commenced and conducted by Colonel Eardley Wilmot, when commanding the Cadet Company at the Royal Military Academy, Woolwich. This physical development seems also to be wanted as a supplement to the high training in the use of the rifle which soldiers now receive. The two combined would make the perfect soldier.

In confirmation of these vicws, and as affording a striking illustration of the evils to be anticipated from an want of proper physical training, I would point to the disaster which befel the American Federal army at Bull's Run.

The "Times" of the 29th instant contains a leading article on the report of the Sanitary Commissioners appointed by the Federal Government to the head-quarters of General MrClellan's army. This report states emphatically that a want of physical training and ability to bear the ordinary hard work of a soldier in the field was one of the causes which led to the severe losses the army experienced.

There does not appear to have been anything extraordinary in the amount of fatigue demanded from the soldiers of this army, and they had 
not been exhausted by previous long marches or an actire campaign, but, as the "Times" says, "It was their very first rapid march and the first loss of a meal which rendered them helpless and unfit for the work of a battle. Here lies the true secret of the whole affair. The men were only soldiers of three months' standing. They had never been inured to privation or eren inconvenience. They could not carry their packs and muskets comfortably for a short march on a cool morning, least of all could they stand a mile or two at the double, which, indeed, might have tried older soldiers than they were. The consequence was, that when they got to the field, though with good training and good arrangements they ought to have been fresh as larks, they were in no condition to do themselves justice. They were brare enough, no doabt, and hat will enough to fight, but they had none of that endurance which training alone can give."

In strong contrast to this, we have only to turn to the famous march of General Crawford's light brigade, which joined the Duke of Wellington after the battle of Talavera, having marched sixty-two English miles in twenty-six hours. Here is an example of what real soldiers could do in those days.

I do not think it necessary to describe similar, though not such energetic, efforts to educate the officer and soldier in Prussia and Austria as in France. The aim is in most respects the same, although the method is different, and the material to be worked upon varies rery much from the impulsive, energetic, and reckless Frank.

The subjects, however, which form the staple for the professional training are identical, and are such as I shall have to touch upon presently.

I cannot, however, avoid inserting a portion of a Report of a mixed commission of military and scientific men presided over by General Lititzow, as alluded to in the Blue Book from which I have already made several extracts.

"Instruction in pure mathenatics in the military academy, particularly in the lower classes, must be considered one of the most important branches of tenching, not merely becatnse the chief points in military science are founded on mathematical principles, but still more because a profound study of mathematics accustoms the heal to clearness, accuracy, and method in thinking."

Again-"Geography, history, and statistics are the sciences by the study of which a young man comes in connection with the world before he knows it practically."

So again as to physical and historical geography-

"It is here particularly that, whilst we give the soldier a sufficient lnnowledge of preparatory science, wo should point its application to the business of war.

"Vithont war, to gain some knowledge of war beforchand, to accustom the mind to throw itself as it were into the most perplexed circumstances of war, and to see what principles are to be applied to them, is certainly a great object in military science. Military geography helps us to do this; first, bccause without it the operations and conduct of a war are not intelligible; sccondly, because the thorough knowledge of a country, both in its inliabitauts and its plyssical geography, helps us to conceive the 
course which any future war will take, and the best mode of conducting it. The first is the more elementary, the latter the higher practical and strategical, branch of the science. And this last requires so much thought and knowledge as to make it undesirable to teach it in a higher school. It should form the employment of a staff school. But detailed suggestions are given for a course of the simple kind of military geography."

That a high degree of professional education is considered necessary for an officer, is clearly shown by the accounts $I$ have given of the system pursued for that object in France; and Prtssia, Austria, Sardinia, and Russia are all engaged in improving military education. In fact it must march with the times, and advance at the same rate as general education and intelligence advances.

In our own service, with the exception of the Artillery and Engincers, the continued education of the officer, apart from the direct professional duties required from. him, such as drills and field mancuvres, has not becn hitherto attempted. The only school at present for officers is the Staff College, where a limited number obtain the infornation requisite to pass the examination for the staff. This appears at present to be the ouly test of professional excellence, and the only way to arrive at distinction in times of peace. This being the case, I almost think that the prize of a staff appointment should be made in a pecuniary sense a more valuable and a more permanent one.

The great mass however of our officers are left to themselves either to work out their education from individual predilections, or else to rest satisfied with that amount of professional information which will enable them to go through their ordinary duties without bungling.

I think that, if the matter were fairly and properly brought before the arny at large, our younger officers would recognise at once the extensive range of information which ought to be mastered to a considerable extent before correct ideas can be entertained even upon merely professional points; and thus the want of a sufficient motive for further education would be satisfactorily met.

Whether in peace or in war, the officer who had tried to mature his judgment and cultivate his reflective powers, other things being equal, would certainly come to the front, and soon bring himself into notice. Is not this a motive strong cnough for a military man?

The formation of camps of instruction in various parts of the United Kingdom is most favourable for carrying out any general scheme for the cducation of the officer, as the means or apparatus necessary to be provided could be better obtained for a large than for a small number.

The instructors would also have the advantage of illustrating their lessons by the actual exhibition of considerable bodies of men under manocuvre. It is possible also that so::nd criticism in relation to tactics and the method of handling troops under certain suppositions, and of occupying ground, might beneficially re-act upon older officers, and induce greater circumspection and consideration in arrnnging for the general drill and maneuvres of a brigade or division.

At first I would therefore recommend that young officers be brought together for the purpose of going through a course of reading on military subjects, such as strategy and tactics as taight by the best military writers. 
If the subjects can be trented in the languages in which they are written, so much the better, but this at all erents might be pursued with a few who were found competent and expressed a. wish to do so.

Special histories should then be selected, which illustrate from actual campaigns the principles contained in the first subjects.

These histories will touch upon the three arms, their combinations and employment, with the special tactics of each arm.

Military topography, as a most essential element of instruction for all military men, will naturally engage a good deal of attention. It forms a very attractire subject for teaching, as it is so intimately connected with all military movements, and the works which treat of it in a military sense are profusely illustrated with examples of movements of armies guided as well as determined by the topographical features of a country. I think that no one could follow up this subject for any length of time without obtaining a large amount of collateral knowledge on military matters of a most useful as well as interesting nature.

Plan-drawing and ficld-sketching, with reports upon routes of communications, could be exceedingly well taught at the camps, and their usefulwess and importance prominently brought into notice.

With the latter should be associated such elementary information upon gcology as will enable an officer to describe the features of a country correctly, and to give other and valuable information dependent upon its gcological formation.

$\Lambda$ knowledge of the ordinary instruments employed for field-sketeling can be obtained with littlo trouble, and particularly if combined with out-of-door practice at the same tine.

The elements of permanent and field fortification would naturally form part of such a course.

The subjects enumerated are all purely professional, and such as can be easily acquired by any one who has the will and determination to make them his study. It remains now for me to show how this can be done, and to point out those authors whom I would recommend to be read and studied on the art and history of war.

lestricting myself still to the camps, I will suppose that military libraries and rooms or halls for study, drawing, and other purposes, are established there.

These neans may possibly be afforded at the public expense, and should be supported by some small contribution from the officers in camp.

$\Lambda$ body of instructors could, I have no doubt, be raised from anongst the officers of the three arms in camp.

Their qualifications however to act as instructors should be satisfactorily inquired into, cither through the medium of the Staff College or through the adjutant-general of each arm.

The anthorities might think it advisable themselves to nominate and pay these instructors; if so, a grent point would be gained.

Should this however not be the case, I should think that any request by a body of junior officers in camp to be instructed as a class in any professional subject would meet with a ready response from some who are capable of imparting the requisite information.

In this way a beginning would be mide, and pressure gently brought 
upon the authorities to provide permanent means for instruction, such for example as are provided in the French regimental schools. I will suppose that the machinery is by some means or other established, artillery, engineers, and staff officers furnishing the instructors.

$A$ class of young officers meet and settle to go through a course comprising the various subjects I have named.

The principal author for selection on strategy, I would recommend to be, without hesitation, the Archduke Charles of Austria; for, although his name does not appear as having really zcritten the work on strategy attributed to him, the work bears such evident internal evidence of the fact, that we need not dispute it.

I would recommend this work to be most carefully gone through, ench officer making a map for himself, if possible, and following step by step the whole course of the campaign, beginning with the passage of the lhine by Moreau at Kehl, and terminating with the siege by the Austrians of this latter place. I would advise, although it might appear tedious, that every step in the operations of this master campaign should be traced.

It will thus prove a valuable lesson, and one which will not soon be efficed from the menory, besides giving. most interesting topographical and geographical knowledge of localities.

Jomini on Strategy may also be strongly recommended, and employed usefully in connection with the former work.

After studying the principles of strategy, and their application to the campaign of 1796 , I would recommend that some of Napoleon's campaigns, for example his first in Italy, commencing with the battle of Montenotte, be examined with reference to the strategy of the campaion, and a memoir on the subject drawn out; or it would perhaps be as interesting to take the campaigns of the Dnlie of Wellington in the Peninsula, and study them in a sinilar manner.

Maxwell's Life of the Duke of Wellington is a very good work to ke taken for this purpose.

There are numerous examples also to be found in Marlborough's campaigns, including his famous march from the Low Countries to the Damube, ending with the battle of Blenhein, which may well serve as studies on strategical combinations: also the Seren Years' War. In fact, once a student becomes interested in the study of this ligher branch of the art of war, the ficld of research opened out to him is incxhaustible.

For the study of tactics there are numcrous forcign authors from whom good selections can be made. It would be well here not to confine oneself too much to one or two authors, but to read several and compare them.

A very claborate work on tactics; containing a great deal of information and general criticism, has been published from the papers left by the Marquis de Ternay, a French nobleman and refugee from the Revolition of 1789. The work has, I believe, been employed in France as a textbook at St. Cyr, and a high commendation is passed upon it by M. Koch, who edits it, as being a work of great merit, and containing just what was required to form a good text-book on tactics, for teaching this branch of the art of war. 
I think, to the English render, it will be found rather, pedantically written, and its style lieavy and too dogmatic; but I also think, from having carefully read it, that there is much matter for reflection, and many judicious remarks.

Jomini is much more likely to interest as a writer, and his range is very considerable, extending throughout the Revolutionary War. Portions of his works may be selected to form a course of reading on tactics, and particularly the earlier campaigns of Buonaparte in Italy, which are considered as affording the best illustrations of the tactics of this great master in the art of war.

Templehoff, the historian of the Seven Years' Tar, and Decker, who has written on the same period (with special reference to the employment of artillery by Frederick the Great), together with General Lloyd's account of the Seven Years' War, may also be considered as valuable authors.

'This period is well illustrated by the Battle of Minden, gained principally through the instrumentality of the English infantry contingent, by their bold attack on the French cavalry, the finest then in Europe, and showing that a tactical error in the disposition of troops on the field of battle may be productive of the greatest disasters. 'Ihis error' was in the disposition of the French cavalry, placed in the centre of the French army, and not sufficiently supported on their flanks.

Many such errors, and the unfortunate results generally attending them, are alluded to by the authors I have named, and should be specially noted for the information of the student.

Special tactics, such as the tactics of the three arms combined, of each separately, or combined two and two, are treated of in several forcign works. The most noteworthy are: Brunét's Histoire d'Artillerie, combining many notices upon the employment of this arm; Decker, de l'Artillerie a Cheval, avec la Cavalerie; Decker, 'Trois Armes; Favé, 'Trois Armes; Decker, Seven Years' War, uoticed above, as showing the employment of artillery in that war.

I know of no English author who has treated of these subjects in a similar way, and I am therefore compelled to allude to forcign writers.

Having read these works, I can safely recommend them to any one as giving a variety of most useful information on the combined action of the several arms. Thought and reflection cannot but be stimulated by at perusal of such authors.

To the cavalry offeer I would particularly recommend the work by Decker on the employment of horse-artillery and cavalry. IIe very justly remarks that either arm is the complement to the other, for, while cavalry possesses the offensive and artillery the defensive clement, the union of the two arms constitutes the perfect military body, having both elements combined.

The first public lecture I ever gave, I recollect, was on the sulject of the manouvres of caralry and horse-artillery, and I found this work invaluable as a text-book; I found that I could make the subject, by means of plans and supposed positions of the troops, both interesting as well as improving; nothing could better show the systematic handling of these troops, or at all events lead to correct views being arrived at on the subject, than such a work. 
On the subject of general military history, and military literature, I would not wish to restrict the taste of any one by limiting his choice to particular authors. - The best are known pretty generally, and good selections could be very well made by the officers instructing.

Some officers would doubtless like to refresh themselves by reading Carsar's Commentaries again; the Chevalier Folard's Polybius would be within the power of any ordinary French scholar to read.

Vegetius on the Military Customs of the Romans, would prove very interesting. The student would trace almost all the modern customs in camp and on the march to the times of the Romans, and discover that General Crawford's orders for the Light Division in the Peninsula were remarkably similar to regulations in practice in the Roman armies.

However, it is more than probable, that, valuable as such reading would be, time would hardly permit of its being pursued to the exclusion of at tolerably complete course upon more modern militury history, relating to operations on ground, and with means and appliances with which we are acquainted, and which to a considerable extent have altered the art of war in some essential particulars.

Topography, by means of the well-known work of La Vallée (which treats of the subject in a purely military seuse), can be made a real means for iuparting extensive military, as well as general, information. The work should be read, at first, in order to gain a general knowledge of the contents, and then employed as a work of reference in connection with the study of particular campaigns.

The work, as published in an abridged form, and translated by Colonel Jackson, contains the military topography of continental Europe, and as such contains all the information necessary for any one studying the general physical features of any country in Europe with reference to military operations in that country. Of course, it would be necessary, for particular purposes, to have more detailed information, and this can be got by the official maps of those countries; but for all educational purposes this work is sufficient.

At first, I would commence by taking a particular country-France, for example, which, as the author's own country, is probably best treated of. A skeleton map should be drawn, for the purpose of filling in afterwards merely the military topography of the country-viz., the frontiers bordering on neighbouring states, showing the physical formation, the natural and artificial obstacles, water-lines, roads, \&c. The lines of fortified places on each side of the frontier would be shown on this map. Particular battle-fields should also be marked, as determining the sites which have been considered both strategetically as well as tactically important.

A knowledge of ancient history would help the student in attaching the proper relative importance to particular places which they have probably always borne-such as Toulouse, the central point of operations for the defence of the South of France, and Lyons, a similar point for the south-castern frontier.

Again, it would be interesting to mark down in different coloured lines the lines of operations pursued by the various armies which have invaded France, commencing with the invasion by the Prussians at the early part of the French Revolution. A map of the above nature, carefully and voL. VI. 
correctly drawn, and with all this information inserted, would give at a glance most valuable and interesting matter for a military man to meditate upon. I shall never forget my feelings when travelling throutgh the Val d'Enfer, or the Höllenthal, in the Black Forest, after reading the stirring account of General Moreau's celebrated retreat through it; or the interest with which I examined the fortifications of Rastadt and tha country leading from it up to the defiles of the Kintzig River, which opens a way through the Black Forest for an arny to reach the higher Danube, after reading the Arch-Duke Charles's account of the retreat of the Austrian army by this route.

The careful study of this work would most certainly induce the habit of studying country with reference to military movements, either for offensive or defensive operations. The mind, as well as the eye, would become educated to regard military operations as based upon an accurate knowledge of the country which is to become the theatre of them, and hardly anything becomes in this eense too insignificant for the military topographer's notice. I allude to this because some not yery thoughtful readers might be inclined to consider that $\mathrm{La}$ Valle goes too much into minutia in his details of apparently insignificant obstacles.

Field-sketching would form a very interesting subject, and many ofticers would soon become quite proficients in this art. The immediate ralue of such an acquirement would be recognised by all, and, together with instruction in the use of the pockct sextant and prismatic compass, would enable an officer to arrive very soon at the next step-riz., laying down and making reports upon routes of communication, with all the collateral information necessary to be furnished to the proper department which has the charge of choosing roads along which troops hare to march in all enemy's country. The highest degree of art in this important branch of daty is when an officer can manage to sketch rapidly and fill in his ronte from horseback. This requires a practised eye and stendy hand; but it is the ultimate point to be aimed at by an officer who wishes to be a proficient in this art.

In order to sketch ground correctly, and give besides as correct information as possible, he should be possessed of some elementary notions on geology. Even a study of heaps of stone on the road-sides is of service, as indicating the nature of the formation in the locality, aud giving also an idea of the probable condition of the roads themselves in bad weather, the indication being drawn from the nature of the materials used to repair them.

Every officer who has not had the advantage of a Sandhurst or Woolwich course should consider it a duty incumbent upon him to obtain a tolerable knowledge of permanent and field fortification, and take every opportunity of making himself perfectly familiur with the details of fortified places, and the relations which the varions works bear to each other for defensive purposes. Should he travel on the continent, he will find numerous examples to study from, and gain also good notions of the improvement in fortification introduced by the German school of late years.

With respect to the periods of the year to be devoted to study, I would recommend a division similar to what $I$ have described in the French regimental schools, viz. the summer season for the practical and out-ofdoor work, and the winter for reading, drawing, and theoretical excrcises. 
General literature, and subjects which, although not strictly professional, are yet portious of. every gentleman's education, need not be dwelt upon here. 'These must be left for each one to select for himself.

My object has been to surgest subjects for study which bear directly on the profession of a soldier, but, in direct connection with all this, there inust be a cultivation of other qualities, which are no less essential, in order to allow of an officer making use of his acquired knowledge for the public benefit. I mean that ready decision of mind and firmness of exccution, which may be called by the name of promptitude, and which, together with knowledge-or, which is the same thing, power-goes far to make a perfect soldier.

If we think of these two qualities, viz. promptitude and power, as summing $u p$ in a general way all that $I$ have said on intellectual and physical education, we shall see by a process of analysis all that is necessary to arrive at the possession of such rare qualities in combination.

A modem author, in a roork entitled "IIorx Subseciva," gives an aturusing though forcible illustration on this very point. He describes in large dor who hats seized a small one by the throat, and is holding him in spite of all endeavours to call him off. Some one proposes to bite his tail; upon which an individual steps out with great alacrity from the crowd, and, seizing the tail of the utrong dog, bites it with determination. For this act he gets knocked over, very properly, by the indignant owner of the small dog. Here, says the anthor, is an exhibition of promptitude without power.

I an afraid we might also class in this category the charge of the Light Brigade at Balaclava. Why is it that so frequently our cavalry, from their individual bravery and crgerness, have called down upon themselves just rebuke rather than praise? Is it not owing to the absence of power, or knowledge, which should curb rashness, and that inclination to prompt action which that arm has frequently exhibited ?

In the Peninsular TVar it was made more than once the occasion of very strong orders on the part of the Duke of Wellington, who reprobated in no measured terms the headlong inpetuosity of the cavalry.

An instance of this unfortunate tendency is also furnished in Sir William Napier's History of the Conquest of Scinde. At the Battle of Hyderabad the precipitate and entirely unauthorised movement of the cavalry posted in observation on the right might have compromised the safety of the entire army. I bring forward these examples, not from any wish to bring discredit on this most gallant arm of the service, but simply to show that judgment based upon professional knowledge can alone bc productive of good results. We may also sometimes see poicer without prompititude, and in either case the loss of the wanting quality is sure to mar a man's usefulness in life.

Then, again, the educated officer is ready for the opportunity when it arrives and is prepared to turn it to acconnt. The old saying that opportunity makes the man, is, I think, entirely wrong, at least as it is generally understood and employed. Far nearer the truth would it be to say that man males the opportunity. In this lies the whole secret of success in life, and from my experience in the work of professional education, and pretty extensive dealing with young men on their first entering life, I can safely say that this rule holds good universally. 